\title{
Menumbuhkan Jiwa Kepemimpinan Pada Mahasiswa di Lingkungan Universitas Pamulang
}

\author{
Syarifah Ida Farida*), Septi Rostika Anjani*) \\ Email: dosen01477@unpam.ac.id,dosen01699@unpam.ac.id
}

\begin{abstract}
ABSTRAK
Menumbuhkan Jiwa Kepemimpinan Pada Mahasiswa di Lingkungan Universitas Pamulang. Penelitian ini bertujuan untuk mengetahui, menganalisis gambaran umum mahasiswa Universitas Pamulang (UNPAM) dan menumbuhkan jiwa kepemimpinan pada mahasiswa di lingkungan Universitas Pamulang. Jenis penelitian ini adalah metode kualitatif. Lokasi penelitian dilakukan di lingkungan UNPAM. Penetapan informan sebagai sumber data yang dipilih menggunakan teknik purposive sampling. Pengumpulan data menggunakan teknik observasi, kuesioner, wawancara, dan dokumentasi. Keabsahan data diperoleh melalui credibility, transferability, dependability, dan confirmatory. Analisis data kualitatif: reduksi, paparan data, dan penarikan kesimpulan. Hasil penelitian menunjukkan kurangnya minat mahasiswa untuk mengikuti kegiatan kokurikuler dan ekstrakulikuler yang ada di lingkungan Universitas Pamulang. Data yang diperoleh peneliti melalui wawancara langsung kepada para responden bahwa kebanyakan mahasiswa hanya fokus kepada pendidikan saja yaitu pembelajaran di kelas. Sedangkan sedikit sekali minat mereka untuk melakukan kegiatan di luar kelas. Beberapa cara yang bisa dilakukan untuk memupuk jiwa kepemimpinan, di antaranya bangunlah pengetahuan, rajinlah membaca; bukalah jendela sel-sel diri sendiri; disiplin diri; bekerjalah dengan prioritas; kerjakan atau delegasikan; bangunlah kepercayaan dan respek; jaga kestabilan emosi; latihlah diri berkomunikasi dan mumpuni; belajarlah menulis; dan gunakan manajemen.Dalam menumbuhkan jiwa kepemimpinan kepada para mahasiswa ada tiga poin penting yaitu leadership (kepemimpinan), team working (kerjasama tim) dan communication (komunikasi). Sedangkan untuk menjadi kepemimpinan yang unggul harus memiliki vision, value and couragevisi, value, courage, competence (kompetensi), strong dan nature character yang didukung dengan tiga kecakapan yang harus dimiliki yaitu kecakapan teknis akademis atau knowledge, kecakapan kemanusiaan atau skill, dan kecakapan spiritual.

Kata kunci: jiwa kepemimpinan, mahasiswa
\end{abstract}

\begin{abstract}
Growing the Spirit of Leadership of Students in The Pamulang University Environment. Purpose of this study was to find out and analyze the general picture of Pamulang University (UNPAM) students, and to understand how to bring up the leadership of Pamulang University students. The type of this research was a qualitative method. The research location was conducted in around of Pamulang University environment. Determination of respondents used purposive sampling technique. Data was collected using observation techniques, questionnaires, direct interviews, and documentation. Qualitative data analysis consisted of reduction, exposing data, and taking a conclusion. The results showed that there was a lack of student interest in participating in the curricular and extracurricular activities at the University of Pamulang. Data obtained by researchers through direct interviews to the respondents showed that most of students only focus on education in the classroom. They had only very little interest to carry out activities in outside the classroom. Many methods that can be done to bring up the leadership, including to build the knowledges how to be diligent in reading; be more open; selfdiscipline; work with priority; work alone or delegate work properly; build up trust and respect; maintain emotional stability; train to increase the capability of communication quality; improve the writing skills; and use management properly. To bring up the spirit of students leadership, there were three important points: leadership, team working and communication. Meanwhile, to be a good leadership must had vision, value and courage, competence, strong and nature character, that it can be supported by three skills: knowledge of academical technique, human capability, and spiritual capability.
\end{abstract}

Keywords: leadership, students

${ }^{*}$ ) dan ${ }^{* *}$ ) Dosen Universitas Pamulang 


\section{PENDAHULUAN}

\section{A. Latar Belakang}

Setiap manusia dilahirkan menjadi seorang pemimpin. Atasan dan pemimpin memiliki makna yang berbeda, atasan memiliki bawahan, anak buah atau pengikut. Sedangkan pemimpin tidak memiliki pengikut seperti yang tersirat dalam makna konvensional kata itu. Pakar kepemimpinan bahkan sudah maju selangkah lebih jauh dengan mengubah pengikut menjadi pemimpin. Bagi pakar kepemimpinan sejati, proses ini tidak hanya melibatkan semua orang di dalam suatu organisasi, tetapi secara harfiah juga semua orang yang ditemuinya. Setiap manusia dilahirkan menjadi seorang pemimpin, antara atasan dan pemimpin memiliki makna yang berbeda. Kalau atasan memiliki bawahan, anak buah atau pengikut, sedangkan pemimpin tidak memiliki pengikut. Pakar kepemimpinan bahkan sudah maju selangkah lebih jauh dengan mengubah pengikut menjadi pemimpin. Bagi pakar kepemimpinan sejati, proses ini tidak hanya melibatkan semua orang di dalam suatu organisasi, tetapi secara harfiah juga semua orang yang ditemuinya.

Selain itu, di dalam hadist riwayat Bukhari, bahwa Rasulullah SAW menegaskan kita semua apa pun jenis kelamin dan status sosialnya di mata manusia, di depan Allah SWT, kita tetaplah seorang pemimpin: "Kalian semua adalah pemimpin dan bertanggung jawab atas apa yang dipimpinnya." Hal tersebut senada dengan pendapat Sri Sultan Hamengku Buwono X bahwa: "Setiap kita sesungguhnya memiliki kapasitas untuk menjadi pemimpin. Kekuatan terdahsyat pemimpin adalah suri teladan (uswatun hasanah) dan kejujuran (siddiq)". Seandainya manusia menyadari bahwa mereka diciptakan di dunia untuk menjadi seorang pemimpin, pastilah di dunia ini damai, sejahtera dan bahagia dunia dan akhirat. Di dalam Al Quran surat Adz-Dzariyat ayat 56: "Tidaklah Kuciptakan jin dan manusia kecuali supaya mereka beribadah kepadaKu". Dari ayat tersebut dapat diketahui tujuan hidup manusia melainkan hanya untuk beribadah kepada Allah SWT. Setiap apa yang dilakukan harus diniatkan ibadah, sehingga manusia dijauhkan dari kesesatan dunia yang fana ini.

Oleh karena itu, peneliti ingin membangkitkan para generasi muda khususnya mahasiswa yang seharusnya sudah memiliki kesadaran yang tinggi untuk memberikan yang terbaik untuk bangsa dan negara. Mahasiswa yang jumlahnya paling banyak di Perguruan Tinggi Swasta di Indonesia adalah Universitas Pamulang (UNPAM). Berdasarkan data dari forlap ristekdikti jumlah mahasiswa Universitas Pamulang sebanyak 72.571 orang. Apabila mahasiswa sebanyak 72.571 orang tersebut memiliki jiwa kepemimpinan dalam diri mereka, akan berdampak yang sangat baik untuk kemajuan UNPAM dan masyarakat maka peneliti mengadakan prasurvey yang dapat dilihat pada Tabel 1.

Berdasarkan hasil prasurvey kepemimpinan dalam diri mahasiswa UNPAM Tahun Akademik 2018-2019 dengan responden sebanyak 20 orang dari Ketua Himpunan Mahasiswa Program Studi dan Ketua Unit Kegiatan Mahasiswa di Universitas Pamulang dapat diketahui dari pernyataan "Saya tidak pernah mencontek" dengan hasil didominasi oleh jawaban "Tidak Setuju" sebanyak 10 orang dari 20 responden, hal ini menandakan bahwa 50\% mereka tidak percaya akan kemampuan mereka 
sendiri sehingga lebih mengandalkan teman ataupun teknologi seperti Handphone dan contekan.

Tabel 1 : Data Pra survey Indikator Kepemimpinan Mahasiswa UNPAM

Tahun Akademik 2018-2019

\begin{tabular}{|c|l|c|c|c|c|c|c|}
\hline No & \multicolumn{1}{|c|}{ Pernyataan } & SS & S & CS & TS & STS & Total \\
\hline 1 & Saya tidak pernah mencontek & 0 & 4 & 5 & 10 & 1 & 20 \\
\hline 2 & Saya tidak suka berbohong & 4 & 5 & 9 & 2 & 0 & 20 \\
\hline 3 & $\begin{array}{l}\text { Saya tidak suka berkata kasar kepada } \\
\text { orang lain }\end{array}$ & 3 & 5 & 10 & 2 & 0 & 20 \\
\hline 4 & Saya memiliki IPK $\geq 3,00$ & 17 & 1 & 1 & 1 & 0 & 20 \\
\hline 4 & Saya memiliki prestasi non akademik & 7 & 4 & 2 & 7 & 0 & 20 \\
\hline 5 & Saya tidak mudah marah & 2 & 5 & 9 & 3 & 1 & 20 \\
\hline
\end{tabular}

Sumber: Data primer diolah oleh peneliti (2019)

Selain itu dari pernyataan "Saya tidak suka berbohong" diketahui bahwa yang menjawab "Cukup Setuju" sebanyak 9 orang (45\%) dari 20 responden, dan pernyataan "Saya tidak suka berkata kasar kepada orang lain" sebanyak 10orang (50\%) dengan menjawab "Cukup Setuju", serta pernyataan "Saya tidak mudah marah" dengan menjawab "Cukup Setuju" sebanyak 9 orang (45\%). Hal ini menandakan bahwa mereka masih membutuhkan pengontrolan diri untuk berbuat jujur.

Dilihat dari prestasi akademik, mereka memiliki Indeks Prestasi Kumulatif di atas 3,00 . Sedangkan prestasi non akademik yang mereka miliki masih rendah yaitu 7 orang $(35 \%)$ yang menjawab "Tidak Setuju". Ada ketidakseimbangan antara Prestasi Akademik dan Prestasi Non Akademik. Untuk mewujudkan generasi muda yang memiliki jiwa kepemimpinan maka dibutuhkan keseimbangan antara kecerdasan intelektual, kecerdasan emosional dan kecerdasan spiritual.

\section{B. Fokus Penelitian}

Permasalahan dalam penelitian kualitatif bertumpu pada suatu fokus. Fokus ini lebih mengarah pada pembaharuan informasi yang diperoleh dari tempat penelitian. Penentuan fokus penelitian ini adalah menumbuhkan jiwa kepemimpinan pada mahasiswa di Lingkungan Universitas Pamulang. Oleh sebab itu, peneliti fokus dalam penelitian ini adalah sebagai berikut.

1. Mendeskripsikan mahasiswa Universitas Pamulang.

2. Menumbuhkan jiwa kepemimpinan mahasiswa di lingkungan Universitas Pamulang.

C. Rumusan Masalah

Mengacu fokus penelitian di atas, maka masalah dirumuskan sebagai berikut:

1. Bagaimana gambaran umum mahasiswa Universitas Pamulang ?

2. Bagaimana menumbuhkan jiwa kepemimpinan pada mahasiswa di lingkungan Universitas Pamulang?

D. Tujuan Penelitian

Berdasarkan rumusan masalah di atas, maka tujuan penelitian ini adalah.

1. Untuk mengetahui dan menganalisis gambaran umum mahasiswa Universitas Pamulang.

2. Untuk mengetahui dan menganalisis bagaimana menumbuhkan jiwa kepemimpinan pada mahasiswa di lingkungan Universitas Pamulang. 


\section{TINJAUAN PUSTAKA}

\section{A. Jiwa Kepemimpinan}

Kepemimpinan (leadership) dapat dimaknai sekumpulan dari serangkaian kemampuan dan sifat-sifat kepribadian yang ada dalam diri pemimpin itu sendiri. Termasuk di dalamnya kewibawaan, keterampilan, pengetahuan, visi dan kompetensi untuk dijadikan sebagai sarana kepemimpinan dalam rangka meyakinkan orang-orang yang dipimpinnya agar mereka mau dan dapat melaksanakan tugas-tugas yang dibebankan kepadanya dengan rela, penuh semangat, ada kegembiraan batin, dan merasa tidak terpaksa.

Pemimpin dengan kepemimpinan berbeda pengertian, kalau pemimpin adalah individu manusianya, sementara kepemimpinan adalah sifat yang melekat kepadanya sebagai pemimpin. Jadi yang dimaksud dengan jiwa kepemimpinan hampir sama dengan kepemimpinan yaitu sifat-sifat kepribadian yang ada di dalam diri manusia itu sendiri yang memiliki kemampuan dalam melaksanakan tugas yang dibebankan kepadanya dengan suka rela dan ikhlas.

Diperlukan 4 (empat) sifat yang sangat mendasar dalam menjalankan kepemimpinan Rasulullah SAW, yakni:

1. Siddiq (jujur), dapat dipercaya. Jujur merupakan suatu hal yang sangat penting di dalam kehidupan manusia. Apabila semua memiliki kepercayaan maka akan meminimalisir biaya.

2. Tabligh (penyampai) yaitu kemampuan bernegosiasi, berkomunikasi, menyampaikan apa yang wajib disampaikan, tidak ada yang disembunyikan.

3. Amanah (benar-benar dapat dipercaya) yaitu bertanggung jawab dalam melaksanakan pekerjaan yang diberikan kepadanya, tanpa ada pengurangan maupun penambahan sehingga ia mendapatkan kepercayaan dari orang lain.

4. Fathanah (cerdas) dalam membuat planning, visi, misi, strategi, implementasi dan pengendaliannya.Fathanah (kecerdasan) merupakan sifat yang harus dimiliki seorang pemimpin yaitu kecerdasan dalam ilmu kepemimpinan.

Tugas pemimpin adalah berupaya memotivasi bawahannya agar dapat berprestasi melampaui harapan dan perkiraan sebelumnya. Esensi kepemimpinan adalah memfasilitasi pengembangan individu untuk merealisasi potensi dirinya. Dalam mengembangkan individu dibutuhkan kemampuan mempengaruhi orang lain dengan menekankan pada kesadaran manusia, tidak dengan memaksa atau dipaksa.

\section{B. Mahasiswa}

Merujuk dari Undang-Undang (UU) Republik Indonesia (RI) No 12 Tahun 2012 tentang Pendidikan Tinggi, Pasal 1 ayat 15 yang menyatakan bahwa mahasiswa adalah peserta didik pada jenjang Pendidikan Tinggi. Jo Pasal 5 butir (a) Pendidikan Tinggi bertujuan mengembangkan potensi Mahasiswa agar menjadi manusia yang beriman dan bertakwa kepada Tuhan Yang Maha Esa dan berakhlak mulia, sehat, berilmu, cakap, kreatif, mandiri, terampil, kompeten, dan berbudaya untuk kepentingan bangsa.

Tujuan tersebut tidak lain untuk menghasilkan lulusan yang menguasai cabang ilmu pengetahuan dan/atau Teknologi untuk memenuhi kepentingan nasional dan 
peningkatan daya saing bangsa; menghasilkan IImu Pengetahuan dan Teknologi melalui Penelitian yang memperhatikan dan menerapkan nilai Humaniora agar bermanfaat bagi kemajuan bangsa, serta kemajuan peradaban dan kesejahteraan umat manusia; serta terwujudnya Pengabdian Kepada Masyarakat berbasis penalaran dan karya penelitian yang bermanfaat dalam memajukan kesejahteraan umum dan mencerdaskan kehidupan bangsa.

Untuk mewujudkan tujuan tersebut dibutuhkan peraturan yang dibuat oleh Pemerintah, Kementerian, LLDIKTI dan Perguruan Tinggi serta Mahasiswa itu sendiri. Hal tersebut ditetapkan dalam UU RI No. 12 Tahun 2012 Pasal 13 bahwa Mahasiswa diposisikan sebagai insan dewasa yang memiliki kesadaran sendiri dalam mengembangkan potensi diri Perguruan Tinggi untuk menjadi intelektual, ilmuwan, praktisi, dan/atau profesional.

\section{METODE PENELITIAN}

\section{A. Pendekatan Penelitian}

Peneliti dalam penelitian ini menggunakan pendekatan penelitian kualitatif atau yang disebut juga dengan penelitian alamiah. Menurut Bogdan dan Taylor, penelitian kualitatif adalah salah satu prosedur penelitian yang menghasilkan data deskriptif berupa ucapan atau tulisan dan perilaku orang-orang yang diamati. Pendekatan kualitatif diharapkan mampu menghasilkan uraian yang mendalam tentang ucapan, tulisan dan atau perilaku yang dapat diamati dari suatu individu, kelompok, masyarakat atau organisasi tertentu yang dikaji dari sudut pandang utuh, komprehensif, dan holistik.

Selain itu peneliti juga menggunakan penelitian deskriptif yaitu untuk mengetahui nilai masing-masing variabel baik satu variabel atau lebih sifatnya independen tanpa membuat hubungan maupun perbandingan dengan variabel yang lain. Penelitian ini berusaha untuk mencari gambaran/deskripsi mengenai bagaimana menumbuhkan jiwa kepemimpinan pada mahasiswa di lingkungan Universitas Pamulang.

\section{B. Sumber Data}

Penelitian menumbuhkan jiwa kepemimpinan pada mahasiswa di lingkungan UNPAM, membutuhkan data yang meliputi:

1. Data primer

Data primer merupakan data langsung yang bersumber dari informan sehubungan dengan relevansi kompetensi. Data primer pada penelitian ini bersumber dari informan kunci yaitu Ketua Himpunan Mahasiswa Program Studi dan Ketua Unit Kegiatan Mahasiswa di UNPAM Tahun Akademik 2018-2019 melalui observasi, kuesioner, dan wawancara.

\section{Data sekunder}

Data sekunder adalah data yang digunakan untuk mendukung data primer berupa dokumen, foto, dan catatan lain yang dapat dipakai sebagai sumber data[11]. Pada penelitian ini, data sekunder diperoleh dari forlap Kementerian Riset, Teknologi dan Pendidikan Tinggi, media online dan buku. 


\section{Populasi dan Sampel}

Penelitian ini tidak mengutamakan besarnya populasi dan sampel, artinya sampel boleh jadi sangat terbatas. Teknik pusposive sampling menjadi teknik pilihan dalam menetapkan informan, dengan tujuan yaitu agar perolehan data sesuai dengan kebutuhan. Teknik yang merupakan teknik penentuan informan dengan berbagai pertimbangan untuk memperoleh informasi yang diperlukan. Pertimbangan tertentu tersebut memiliki arti bahwa subyek yang dipilih paling penting dan tahu tentang yang diharapkan atau mungkin dia sebagai penguasa sehingga akan memudahkan peneliti menjelajahi situasi sosial yang diteliti. Sedangkan sampel penelitian kualitatif dapat sebagai nara sumber, partisipan atau informan, yaitu Ketua HIMA Prodi dan Ketua UKM sebanyak 20 responden.

\section{Teknik Pengumpulan Data}

Teknik pengumpulan data merupakan langkah yang paling utama dalam penelitian, karena tujuan utama dari penelitian adalah mendapatkan data. Tanpa mengetahui teknik pengumpulan data, maka peneliti tidak akan mendapatkan data yang memenuhi standar data yang ditetapkan. Teknik pengumpulan data yang peneliti gunakan untuk menjawab permasalahan penelitian dengan menggunakan observasi, kuesioner, wawancara dan dokumentasi. Untuk keabsahan data digunakan triangulasi sumber yaitu penggalian kebenaran melalui berbagai metode dan sumber perolehan data[12]. Uji keakurasian data dilakukan dengan croscek data dari sumber data yang berbeda. Selanjutnya data diidentifikasi, dikategorikan, direduksi dan ditarik kesimpulan.

\section{E. Teknik Analisis Data}

Analisis data adalah proses mencari dan menyusun secara sistematis data yang diperoleh dari hasil wawancara, catatan lapangan, dan bahan-bahan lain, sehingga dapat mudah dipahami, dan temuannya dapat diinformasikan kepada orang lain. Analisis data dalam penelitian ini yaitu Reduksi Data (Data Reduction), Paparan Data (Data Display), Penarikan Kesimpulan Data dan Verifikasi (Conclusion Drown/Verification).

\section{HASIL PENELITIAN DAN PEMBAHASAN}

\section{A. Gambaran Umum Mahasiswa di Lingkungan Universitas Pamulang}

Mahasiswa merupakan aset terbesar bagi perguruan tinggi, masyarakat dan negara. Output yang harus mereka dapatkan dari perguruan tinggi adalah menjadi lulusan yang mampu memberikan ilmunya sesuai dengan kompetensinya. Ilmu yang mereka dapatkan bukan hanya dari dalam kelas tetapi juga di luar kelas. Dari luar kelas mereka bisa dapatkan melalui kegiatan mahasiswa baik di tingkat universitas maupun program studi atau di lingkungan tempat mereka berada.

Berdasarkan hasil pengamatan atau observasi yang peneliti lakukan di Universitas Pamulang dapat dilihat perbedaan mahasiswa yang tidak mengikuti organisasi dan yang mengikuti organisasi. Mahasiswa yang tidak pernah mengikuti organisasi 
perilakunya lebih pendiam dan kurang percaya diri. Oleh karena itu, dibutuhkan jiwa kepemimpinan dalam diri mahasiswa itu sendiri dengan cara mengembangkan potensinya melalui pembelajaran, pencarian kebenaran, dan/atau penguasaan, pengembangan, dan pengamalan suatu cabang ilmu pengetahuan dan/atau teknologi untuk menjadi ilmuwan, intelektual, praktisi, dan/atau profesional yang berbudaya. Selain itu mahasiswa ditingkatkan daya nalar mereka dengan mengikuti kegiatan yang ada di kampus maupun di luar kampus.

Untuk meningkatkan daya nalar tersebut Perguruan Tinggi memberikan pelayanan Pendidikan sesuai dengan bakat, minat, potensi, dan kemampuannya. Mahasiswa mengembangkan bakat, minat, dan kemampuan dirinya melalui kegiatan kokurikuler dan ekstrakurikuler sebagai bagian dari proses pendidikan yang dapat dilaksanakan melalui organisasi kemahasiswaan yang diatur dalam statuta Perguruan Tinggi.[9]Berdasarkan data dari forlap Kementerian Riset, Teknologi, dan Pendidikan Tinggi yaitu jumlah mahasiswa Universitas Pamulang yang aktif di Semester Genap Tahun Akademik 2018-2019 sebanyak 72.571 orang yang terdiri dari 6 (enam) Fakultas dengan 13 (tiga belas) Program Sarjana, 2 (dua) Program Diploma dan 2 (dua) Program Magister.

Tabel 2. : Fakultas dan Program Studi di UNPAM, Tahun Akademik 2018-2019

\begin{tabular}{|c|c|c|c|c|c|}
\hline No & Fakultas & & Program Studi & Program & Jumlah Mahasiswa Aktif \\
\hline \multirow[t]{2}{*}{1.} & \multirow[t]{2}{*}{ Hukum } & 1. & IImu Hukum & Sarjana & 5.537 \\
\hline & & 2. & IImu Hukum & Magister & 407 \\
\hline \multirow[t]{5}{*}{2.} & \multirow[t]{5}{*}{ Ekonomi } & 3. & Manajemen & Sarjana & 24.064 \\
\hline & & 4. & Akuntansi & Sarjana & 11.639 \\
\hline & & 5. & Akuntansi & Diploma & 1.554 \\
\hline & & 6. & Sekretari & Diploma & 1.228 \\
\hline & & 7. & Manajemen & Magister & 934 \\
\hline 3. & MIPA & 8. & Matematika & Sarjana & 795 \\
\hline \multirow[t]{2}{*}{4.} & \multirow{2}{*}{$\begin{array}{l}\text { Keguruan dan IImu } \\
\text { Pendidikan }\end{array}$} & 9. & Pendidikan Ekonomi & Sarjana & 1.457 \\
\hline & & 10 & $\begin{array}{l}\text { Pendidikan Pancasila } \\
\text { dan Kewarganegaraan }\end{array}$ & Sarjana & 1.363 \\
\hline \multirow[t]{2}{*}{5.} & \multirow[t]{2}{*}{ Sastra } & 11 & Sastra Indonesia & Sarjana & 1.625 \\
\hline & & 12 & Sastra Inggris & Sarjana & 3.457 \\
\hline \multirow[t]{5}{*}{6.} & \multirow[t]{5}{*}{ Teknik } & 13 & Teknik Elektro & Sarjana & 2.048 \\
\hline & & 14 & Teknik Industri & Sarjana & 2.713 \\
\hline & & 15 & Teknik Informatika & Sarjana & 10.481 \\
\hline & & 16 & Teknik Kimia & Sarjana & 537 \\
\hline & & 17 & Teknik Mesin & Sarjana & 2.732 \\
\hline \multicolumn{5}{|c|}{ Total } & 72.571 \\
\hline
\end{tabular}

Sumber: forlap.ristekdikti.go.id. (2019) 
Adapun jumlah pengurus dari Unit Kegiatan Mahasiswa (UKM) pada Universitas Pamulang Tahun Akademik 2018-2019 yang terdiri dari Ketua sampai dengan Anggota dapat dilihat pada Tabel 3.

Tabel 3 : Jumlah Pengurus Unit Kegiatan Mahasiswa pada UNPAM 2018-2019

\begin{tabular}{|c|l|c|}
\hline No & \multicolumn{1}{|c|}{ Nama UKM } & Jumlah Pengurus \\
\hline 1. & UKM Archa Buana & 12 \\
\hline 2. & UKM Racana Adhyaksa Tirta Buana-Dewi Puspita & 40 \\
\hline 3. & UKM PSM Gita Sasmita & 50 \\
\hline 4. & UKM Scooter & 14 \\
\hline 5. & UKM Olahraga & 15 \\
\hline
\end{tabular}

Sumber: Data Primer (2019)

Sedangkan jumlah pengurus dari Himpunan Mahasiswa Program Studi di Universitas Pamulang hanya sedikit sekali dibandingkan jumlah mahasiswa aktif Tahun Akademik 2018-2019 yang dapat dilihat pada Tabel 4.

Tabel 4 : Rasio Jumlah Pengurus Himpunan Mahasiswa Program Studi dengan Jumlah Mahasiswa Aktif di UNPAM Tahun Akademik 2018-2019

\begin{tabular}{|c|l|c|c|c|}
\hline No. & \multicolumn{1}{|c|}{ Program Studi } & $\begin{array}{c}\text { Jumlah Pengurus } \\
\text { HIMA Prodi }\end{array}$ & $\begin{array}{c}\text { Jumlah } \\
\text { Mahasiswa Aktif }\end{array}$ & Rasio \\
\hline 1 & Manajemen (S-1) & 140 & 24.064 & $1 \%$ \\
\hline 2 & Akuntansi (D-3) & 12 & 1.554 & $1 \%$ \\
\hline 3 & Sekretari & 19 & 1.228 & $2 \%$ \\
\hline 4 & Teknik Industri & 50 & 2.713 & $2 \%$ \\
\hline 5 & Matematika & 33 & 795 & $4 \%$ \\
\hline 6 & Pendidikan Ekonomi & 60 & 1.457 & $4 \%$ \\
\hline 7 & Teknik Mesin & 60 & 2.732 & $2 \%$ \\
\hline 8 & Teknik Kimia & 20 & 537 & $4 \%$ \\
\hline 9 & Sastra Inggris & 31 & 3.457 & $1 \%$ \\
\hline 10 & Sastra Indonesia & 20 & 1.625 & $1 \%$ \\
\hline 11 & Akuntansi (S-1) & 12 & 11.639 & $0 \%$ \\
\hline 12 & Teknik Elektro & 28 & 2.048 & $1 \%$ \\
\hline 13 & Hukum & 25 & 5.537 & $0 \%$ \\
\hline 14 & Prodi Teknik Informatika & 52 & 10.481 & $0 \%$ \\
\hline 15 & Prodi Pendidikan Pancasila dan & 30 & 1.363 & $2 \%$ \\
\hline
\end{tabular}

Sumber: Data diolah oleh peneliti (2019)

Berdasarkan data di tabel 4 dapat dilihat bahwa kurangnya minat mahasiswa untuk mengikuti kegiatan kokurikuler dan ekstrakulikuler yang ada di lingkungan Universitas Pamulang. Data yang peneliti peroleh melalui wawancara langsung kepada para responden bahwa kebanyakan mahasiswa hanya fokus kepada pendidikan saja yaitu pembelajaran di kelas. Sedangkan sedikit sekali minat mereka untuk melakukan kegiatan di luar kelas.

Responden yang terdiri dari Ketua Himpunan Mahasiswa Program Studi dan Ketua Unit Kegiatan Mahasiswa (UKM) hampir didominasi oleh perempuan, dengan perbandingan laki-laki sebanyak $55 \%$ dan perempuan $45 \%$. 
Tabel 5 : Jumlah Jenis Kelamin Responden

\begin{tabular}{|c|c|c|}
\hline Jenis Kelamin & Jumlah & Persentase \\
\hline Laki-laki & 11 & $55 \%$ \\
\hline Perempuan & 9 & $45 \%$ \\
\hline Total & $\mathbf{2 0}$ & $\mathbf{1 0 0} \%$ \\
\hline
\end{tabular}

Sumber: Data diolah oleh peneliti (2019)

Hal ini menandakan bahwa siapa pun memiliki jiwa kepemimpinan tanpa membedakan jenis kelamin. Senada dengan hadist riwayat Bukhari, bahwa Rasulullah SAW menegaskan kita semua apa pun jenis kelamin dan status sosialnya di mata manusia, di depan Allah SWT, kita tetaplah seorang pemimpin: "Kalian semua adalah pemimpin dan bertanggung jawab atas apa yang dipimpinnya. Seorang penguasa adalah pemimpin dan dia bertanggung jawab atas rakyatnya. Seorang pria adalah pemimpin bagi keluarganya, dan bertanggung jawab atas apa yang dipimpinnya. Seorang istri adalah pemimpin di rumah suaminya, dan dia bertanggung jawab atas apa yang dipimpinnya. Seorang pembantu adalah pemimpin bagi harta majikannya, dan dia bertanggung jawab atas apa yang dipimpinnya". Hal tersebut sependapat dengan Sri Sultan Hamengku Buwono X bahwa: "Setiap kita sesungguhnya memiliki kapasitas untuk menjadi pemimpin. Kekuatan terdahsyat pemimpin adalah suri teladan (uswatun hasanah) dan kejujuran (siddiq)".

\section{B. Jiwa Kepemimpinan Mahasiswa di Lingkungan Universitas Pamulang}

Dalam penelitian ini peneliti memberikan kuesioner kepada para responden mengenai faktor kepemimpinan yang ada pada diri mereka sendiri. Untuk mengetahui seberapa besar faktor kepemimpinan yang dimiliki oleh para responden, dibuatkan kuesioner dengan 26 pernyataan yang diisi dengan nilai 1 sampai 5. Dimana 1 adalah paling tidak setuju atau paling tidak sesuai sedangkan nilai 5 adalah paling setuju atau paling sesuai dengan responden. Adapun pernyataannya dapat dilihat pada Tabel 6.

Tabel 6 : Pernyataan Kuesioner Faktor Kepemimpinan

\begin{tabular}{|l|l|}
\hline No & \multicolumn{1}{|c|}{ Pernyataan } \\
\hline 1. & $\begin{array}{l}\text { Untuk mendapatkan yang terbaik dari seseorang lebih baik mendukung mereka } \\
\text { daripada menyetir mereka. }\end{array}$ \\
\hline 2. & Kerjasama lebih efektif daripada kepemimpinan yang kuat. \\
\hline 3. & Saya memegang teguh tanggung jawab saya. \\
\hline 4. & $\begin{array}{l}\text { Setiap orang harus diperlakukan sama apapun kesalahan, ketidaksempurnaan, } \\
\text { pendapat, kepercayaan dan status mereka. }\end{array}$ \\
\hline 5. & Saya memiliki potensi untuk berada di puncak profesi pilihan saya. \\
\hline 6. & $\begin{array}{l}\text { Sebuah tim hanya bisa bekerja menggunakan potensi maksimal mereka apabila ada } \\
\text { seseorang yang memegang kendali keseluruhan. }\end{array}$ \\
\hline 7. & Saya menghargai kritik. \\
\hline 8. & $\begin{array}{l}\text { Keterampilan berhubungan dengan orang lebih penting daripada memimpin dengan } \\
\text { teladan. }\end{array}$ \\
\hline 9. & Hidup adalah permainan tim. \\
\hline 10. & $\begin{array}{l}\text { Memiliki kemampuan menjalankan perintah sama pentingnya dengan memiliki } \\
\text { kemampuan memberi perintah. }\end{array}$ \\
\hline
\end{tabular}


JURNAL ILMIAH ILMU MANAJEMEN

\begin{tabular}{|l|l|}
\hline No & \multicolumn{1}{|c|}{ Pernyataan } \\
\hline 11. & Saya lebih suka melakukan kesenangan saya daripada mengikuti trend an mode. \\
\hline 12. & Saya meyakini pentingnya mengikuti perkembangan teknologi baru. \\
\hline 13. & Saya tidak kesulitan mencurahkan semua enerji saya ke dalam pekerjaan saya. \\
\hline 14. & Anda tidak pernah terlalu tua untuk belajar. \\
\hline 15. & $\begin{array}{l}\text { Sebuah tim berada pada kekuatan puncak saat semua anggota tim menyatu dengan } \\
\text { tujuan tim. }\end{array}$ \\
\hline 16. & Saya sangat mempercayai penilaian bawahan secara teratur \\
\hline 17. & Tim atau organisasi manapun hanya bisa sekuat matarantai terlemah mereka. \\
\hline 18. & Kesetiakawanan penting dalam membangun tim yang sukses. \\
\hline 19. & Saya melihat diri saya lebih sebagai pemimpin daripada sebagai pengikut. \\
\hline 20. & $\begin{array}{l}\text { Mendelegasikan tangung jawab lebih penting daripada membagi beban kerja secara } \\
\text { merata di antara semua anggota tim. }\end{array}$ \\
\hline 21. & Saya akan menjadi politisi yang baik dan efektif. \\
\hline 22. & $\begin{array}{l}\text { Saya akan sangat kecewa jika seorang rekan kerja saya selama bertahun-tahun pada } \\
\text { kedudukan yang sama tiba-tiba diangkat menduduki posisi senior di atas saya }\end{array}$ \\
\hline 23. & Saya menyukai mengendalikan situasi dari pada mengikuti arus. \\
\hline 24. & $\begin{array}{l}\text { Seorang pemimpin yang secara teknis di bawah kualifikasi lebih disukai daripada } \\
\text { pemimpin tim yang sangat mengganggu }\end{array}$ \\
\hline 25. & Saya sangat menikmati mengorganisasi berbagai hal \\
\hline 26. & Semakin besar tantangan, semakin besar upaya yang dibutuhkan \\
\hline
\end{tabular}

Sumber: Bachrun (2014)

Dari score atau nilai yang didapatkan kemudian dikualifikasi menjadi:

Nilai $115-130$ : faktor kepemimpinan yang luar biasa tinggi

Nilai $105-114$ : faktor kepemimpinan yang sangat tinggi

Nilai $95-104$ : faktor kepemimpinan yang tinggi

Nilai $85-94$ : faktor kepemimpinan yang di atas rata-rata

Nilai 75-84 : faktor kepemimpinan yang rata-rata

Niai $60-74$ : faktor kepemimpinan yang di bawah rata-rata

Nilai $50-59$ : faktor kepemimpinan sangat rendah.

Dari hasil jawaban para responden tersebut, peneliti olah datanya dan didapatkan jumlah responden yang memiliki faktor kepemimpinan yang luar biasa tinggi sampai dengan faktor kepemimpinan yang di atas rata-rata dapat dilihat pada Tabel 7 .

Tabel 7 : Data Faktor Kepemimpinan Ketua HIMA Prodi dan Ketua UKM Universitas Pamulang Tahun Akademik 2018-2019

\begin{tabular}{|l|c|l|c|c|}
\hline No & Nilai/Score & \multicolumn{1}{|c|}{ Kualifikasi } & $\begin{array}{c}\text { Jumlah } \\
\text { Responden }\end{array}$ & Persentase \\
\hline 1. & $115-130$ & Faktor kepemimpinan yang luar biasa tinggi & 3 & $15 \%$ \\
\hline 2. & $105-114$ & Faktor kepemimpinan yang sangat tinggi & 4 & $20 \%$ \\
\hline 3. & $95-104$ & Faktor kepemimpinan yang tinggi & 9 & $45 \%$ \\
\hline 4. & $85-94$ & Faktor kepemimpinan yang di atas rata-rata & 4 & $20 \%$ \\
\hline \multicolumn{2}{|c|}{ Total } & $\mathbf{2 0}$ & $\mathbf{1 0 0 \%}$ \\
\hline
\end{tabular}

Sumber: Data diolah oleh peneliti (2019)

Berdasarkan data pada Tabel 7 dapat dilihat bahwa dari 20 responden yang memiliki "Faktor kepemimpinan yang luar biasa tinggi" yaitu sebanyak 3 orang (15\%), 
yang memiliki "Faktor kepemimpinan yang sangat tinggi" yaitu sebanyak 4 orang (20\%), dan yang paling banyak pada kualifikasi "Faktor kepemimpinan yang tinggi" yaitu sebanyak 9 orang $(45 \%)$, sedangkan "Faktor kepemimpinan yang di atas ratarata sebanyak 4 orang (20\%).Dari data tersebut dapat diketahui bahwa masih dibutuhkan pelatihan kepemimpinan untuk para pengurus HIMA Prodi dan UKM sehingga mereka memiliki jiwa kepemimpinan yang luar biasa tinggi dan juga bisa mencetak mahasiswa lainnya menjadi pemimpin yang lebih baik lagi. Seorang pemimpin dikatakan berhasil apabila bisa menghasilkan pemimpin yang lebih baik lagi di masa yang akan datang.

\section{Menumbuhkan Jiwa Kepemimpinan Mahasiswa di Lingkungan Universitas Pamulang}

Kepemimpinan adalah kegiatan untuk memengaruhi perilaku orang lain, atau seni memengaruhi perilaku manusia baik perorangan maupun kelompok. Dari pengertian tersebut kepemimpinan tidak harus dibatasi oleh aturan-aturan atau tata krama birokrasi. Kepemimpinan tidak harus diikat dalam suatu organisasi tertentu. Melainkan kepemimpinan bisa terjadi di mana saja, asalkan seseorang menunjukkan kemampuannya memengaruhi perilaku orang-orang lain ke arah tercapainya suatu tujuan tertentu.

Berdasarkan data yang diperoleh melalui wawancara kepada para responden, selama mereka menjadi Ketua Himpunan Mahasiswa Program Studi dan Ketua Unit Kegiatan Mahasiswa banyak memberikan kesan yang mendalam dan mengalami banyak perubahan dalam kehidupan mereka sehari-hari, diantaranya sebagai berikut menjadi lebih percaya diri, berani tampil di depan banyak orang, memiliki keterampilan komunikasi yang lebih baik, mendapatkan pengalaman yang banyak, memberikan manfaat kepada warga yang membutuhkan seperti mengadakan bakti sosial, dan bertanggung jawab.

Perubahan tersebut secara tidak langsung didapatkan dari dalam diri mahasiswa itu sendiri, pengalaman dan dorongan dari orangtua. Untuk menciptakan generasi masa depan yang lebih baik lagi dapat dilakukan melalui pengarahan, pengembangan diri, dan pelatihan terutama membentuk jiwa kepemimpinan (leadership) sehingga tumbuh sebagai generasi penerus bangsa yang tangguh, kuat, berbudi pekerja, rela berkorban, tanggung jawab, cinta tanah air, dan berjiwa Pancasila. Program latihan kepemimpinan yang tepat dan sukses bagi remaja dilakukan dengan tiga tahapan antara lain, tahapan pertama adalah menentukan tujuan, karena tujuan merupakan pedoman bagi penentu kebijakan pengembangan dan pendidikan kepemimpinan; tahapan kedua, menentukan kebutuhan latihan yaitu bekal keterampilan yang dibutuhkan oleh seorang pemimpin yang efektif; tahapan ketiga, memilih materi-materi yang tepat dan dapat memberikan motivasi untuk mengadakan perubahan sikap, dapat melancarkan komunikasi, serta membangun kerjasama dengan semua baik atasan, teman sejawat yang sederajat, maupun bawahan.

Berdasarkan hasil wawancara dapat disimpulkan karakteristik pemimpin yang diinginkan para responden sesuai dengan karakteristik kepemimpinan yang ada di dalam diri Rasulullah S.A.W., diantaranya sebagai berikut : 
1) Jujur,

2) Menjaga kepercayaan/amanah,

3) Menepati janji,

4) Menjadi peran model,

5) Cakap dalam manajemen waktu,

6) Berwawasan luas,

7) Ahli memecahkan konflik,

8) Menghargai bawahan,

9) Bersikap profesional dan adil,

10) Cakap dalam mengelola emosi,

11) Cakap dlm manjajemen keuangan,

12) Menghargai perbedaan,

13) Pergaulan luas,

Ciri kepemimpinan Nabi Muhammad saw, dikristilisasi menjadi lima (Moeljono D., 2017) yaitu pertama, Nabi adalah seorang pemimpin yang benevolent, atau pemimpin yang murah hati, penyabar, penuh kasih sayang, pemaaf, mengedepankan nilai kemanusiaan, dan keimanan dan kesetiaan yang tulus kepada Allah SWT. yang disebut memanusiakan manusia di depan Khaliq-nya. Ciri yang kedua yaitu membawa perubahan yang memberikan proses yang baik dan hasil yang paripurna. Ketiga, Nabi Muhammad saw. adalah pemimpin yang meneladani atau walk the talk, apa yang diucapkan, maka dilaksanakan dengan konsisten, dan tanpa kompromi. Keempat, mempunyai rangkaian ciri unggul seorang pemimpin yaitu adil, jujur, inovatif, berwawasan ke depan atau visoner, tegas, tapi rendah hati, pemberani tapi bersahaja, kuat fisik dan tahan penderitaan tanpa meninggalkan kualitas kepemimpinannya yang asli. Kelima, Nabi bukan hanya seorang leader, tetapi manager-leader, karena mempunyai kompetensi seorang manajer. Nabi menguasai manajemen waktu, manajemen sumber daya manusia, hingga manajemen keuangan, dan manajemen strategis-ahli dalam peperangan.

Selain itu, dalam menumbuhkan jiwa kepemimpinan kepada para mahasiswa ada tiga poin penting yaitu leadership (kepemimpinan), team working (kerjasama tim) dan communication (komunikasi). Poin pertama yaitu tentang Leadership (kepemimpinan). Dalam hal ini, kepemimpinan (leadership) mahasiswa yang perlu dikembangkan adalah self leadership atau pemimpin untuk diri sendiri. Setiap mahasiswa memiliki kemampuan untuk diberikan suatu tanggung jawab pada hal-hal yang ia kerjakan, hal ini sebagai pelatihan untuk membentuk jiwa kepemimpinan dalam dirinya. Tanggung jawab itu dapat diberikan berupa tugas-tugas dalam aktivitas sehari-hari, sehingga menambah rasa percaya diri mahasiswa dan mampu menerima tantangan dalam hidupnya, hal itu sangat berpengaruh dalam mengasah jiwa kepemimpinannya.

Poin kedua yaitu kerja tim (team working), untuk menumbuhkan kerja tim pada mahasiswa, orang-orang disekitarnya seperti orang tua, sahabat, teman dan lingkungan harus mendukung para remaja untuk dapat bersosialisasi dan mengerjakan segala hal yang membutuhkan kerjasama. Kerja tim (team working) ditumbuhkan untuk 
menumbuhkan kepekaan mahasiswa pada orang atau lingkungan sekitarnya, sehingga kelak akan mempengaruhi sikap atau gaya kepemimpinan remaja dimasa depan.

Poin ketiga yaitu komunikasi (communication). Komunikasi berarti menyampaikan pesan atau informasi dalam berbagai cara agar terjadi suatu komunikasi antar beberapa individu di dalamnya. Bagi seorang mahasiswa yang akan menjadi seorang pemimpin, maka komunikasi harus diasah sejak dini untuk kepemimpinan yang mampu berkomunikasi dengan baik. Untuk mengasah keterampilan komunikasi pada remaja, hal pertama yang menjadi dasar yaitu rasa percaya diri. Dalam diri mahasiswa harus ditanamkan rasa percaya diri bahwa para mahasiswa mampu menyampaikan sesuatu yang menjadi pandangannya. Dengan rasa percaya diri dan sikap untuk terus belajar maka kemampuan remaja akan semakin meningkat.

Ketiga langkah tersebut dapat diwujudkan dalam mengikuti kegiatan kokurikuler dan ekstrakurikuler baik yang ada di dalam kampus maupun di luar kampus. Temuan penelitian tentang pembelajaran di dalam dan di luar kelas mendukung pernyataan Soutworth (2002), Hallinger (2003), dan Bush \& Glover (2003) yang menyatakan kepemimpinan pembelajaran adalah kepemimpinan yang fokus pada pembelajaran. Pembelajaran di sini meliputi pembelajaran di kelas dan di luar kelas.

Pembelajaran tersebut dibutuhkan pemimpin yang bisa memberikan pengarahan kepada para anggotanya. Menurut Carnegie ada beberapa hal yang dibutuhkan pemimpin masa kini yaitu otoritas yang sah, keyakinan diri yang otentik, percaya diri dengan fleksibel, menerima resiko dan kebulatan tekad. Sedangkan untuk meningkatkan kemampuan kepemimpinan ada beberapa langkah yang spesifik yaitu berfokus pada gambaran besar, berambisi, mengenal diri sendiri, bersikap tegas, mengendalikan stres, menerima kritik, bersedia mendengarkan, bersikap fleksibel, bersikap mendukung, memberi dorongan pada orang lain, merayakan keberhasilan, mendukung bawahan, meringankan beban, menerima tanggung jawab, memecahkan masalah, melakukan dengan benar, bersikap jujur, menghindari gosip, melakukan yang terbaik dan mengkritik secara konstruktif.

Menjadi pemimpin yang terutama adalah bagaimana kita memiliki kualitas trianguler di antaranya adalah intellectual quality, emotional quality, dan spiritual quality. Kualitas intelektual membuat kita mampu memilah data, informasi dan opini yang dipertanggungjawabkan kepada keilmuan dan standard-operating-procedures. Data emosional akan menunjukkan bahwa kita mempunyai kemampuan untuk membuat keputusan dengan tepat, cepat, dan akurat, yang dipertanggungjawabkan kepada manusia-manusia lain yang terkait sebagai manusia. Sedangkan dengan penguasaan spiritual quality kita mempunyai fondasi nilai bahwa keputusan yang kita buat, apa pun keputusan itu, harus bisa dipertanggungjawabkan sendiri dan diminta setelah kita mati dan menghadap Allah SWT.

Berdasarkan hasil wawancara dengan ahli Leadership yaitu Prof. Dr. Djokosantoso Moeljono bahwa "seorang pemimpin yang ingin berhasil, hendaknya menyadari bahwa landasan utama seorang profesional adalah memiliki sikap disiplin yang tinggi dengan dasar kehormatan yang mendalam. Selain itu, sebagai seorang 
pemimpin harus memahami secara mendalam bahwa memimpin adalah amanah, kewajiban dan bukan hak, pimpinlah dengan kebersihan nurani".

Kepempimpinan sebenarnya memiliki dua makna, yang pertama bahwa yang bersangkutan diterima di lingkungannya sebagai seorang pemimpin, baik formal maupun informal. Kedua, sebuah karakter yang pasti dimiliki setiap manusia sebagai ciptaan Tuhan. Penasehat manajemen Dale Carnegie mengatakan bahwa "Ada kepemimpinan di dalam setiap diri Anda". Apa yang dikatakan sama seperti yang tertulis di Al-Qur'an maupun Alkitab, bahwa manusia diciptakan Tuhan untuk memimpin alam semesta. Gofford mengemukakan bahwa beberapa organisasi lebih maju karena terdapat banyak pemimpin. Ke depannya pekerjaan-pekerjaan oleh otot semakin ditinggalkan oleh pekerjaan yang mengandalkan pengetahuan. Peter Ducker membuat karakteristik sederhana mengenai syarat pemimpin dan kepemimpinan, yaitu:

1. Dicirikan dari adanya pengikut.

2. Pemimpin efektif bukanlah selalu seseorang dipuja atau dicintai, namun mereka adalah individu yang menjadikan para pengikutnya berbuat benar. Kepemimpinan berbeda dengan popularitas. Kepemimpinan identik dengan pencapaian hasil.

3. Pemimpin adalah mereka yang sangat tampak. Karenanya mereka harus memberikan contoh.

4. Kepemimpinan adalah tanggung jawab, bukanlah kedudukan, jabatan, atau uang. Untuk menjadi kepemimpinan yang unggul harus memiliki tiga serangkai kepemimpinan yaitu vision, value and courage:

a. Visi

Pemimpin harus memiliki visi kemana organisasi akan dibawa, dan selanjutnya bagaimana strategi serta implementasinya. Organisasi dengan pemimpin yang tidak memiliki visi adalah organisasi yang menunggu waktu untuk lenyap, begitupula dengan manusia tanpa visi, manusia akan lenyap.

b. Value

Visi saja tidak cukup, maka dibutuhkan value. Nilai dari seorang pemimpin akan menentukan apakah ia bisa menjadi pemimpin yang efektif atau tidak. Sesungguhnya ada dua jenis nilai pemimpin, yaitu pemimpin yang berorientasi kepada diri sendiri dan yang berorientasi kepada organisasi.

c. Courage

Visi dan value saja tidak cukup, dibutuhkan courage. Tidak ada gunanya visi dan nilai apabila tidak memiliki keberanian untuk mengambil keputusan. Inti dari kepemimpinan mengambil keputusan. Setiap keputusan pasti mengandung kesalahan di dalam dirinya.

Namun, dalam perjalanan praktik dan pembelajaran VVC saja tidak cukup. Ada fondasi lain yang diperlukan: competence (kompetensi), strong dan nature character. Fondasi competence (kompetensi), adalah kecakapan yang sesuai untuk melaksanakan tugasnya. Tugas pemimpin adalah mengambil keputusan secara efektif (termasuk di dalamnya efisien). Untuk bisa mencapai keputusan yang menghasilkan 
profit maka ia harus memiliki kecakapan yang cukup sebagai pendukung keputusan yang dibuat. Tiga jenis kecakapan di antaranya sebagai berikut :

1. Kecakapan teknis akademis atau knowledge Kecakapan ini adalah kecakapan-kecakapan yang dapat diajarkan dan dipelajari dalam teori-teori kepemimpinan, mulai dari proses pembuatan keputusan dari identifikasi masalah ke pengumpulan informasi, kemudian seleksi alternatif keputusan, dan akhirnya pembuatan keputusan, hingga teknik-teknik kepemimpinan lainnya.

2. Kecakapan kemanusiaan atau skill

Kecakapan untuk mentransfer pengetahuan menjadi praktik dan bersifat aplikatif, contohnya kemampuan untuk melaksanakan praktik kepemimpinan, mengembangkan wawasan, dan membangun jaringan kerja sama yang luas dalam rangka tugas kepemimpinannya.

3. Kecakapan spiritual

IQ dan EW (termasuk EI) baru bersentuhan dengan akuntabilitas dengan manusia, yaitu dari akuntabilitas hierarki terdasar, dengan pribadi, hingga jenjang kelima, dengan stakeholders-nya. Ketika akuntabilitas harus dibawa ke jenjang tertinggi, dengan Tuhan Yang Maha Kuasa, manusia memerlukan Spiritual Intelegensi (SI).

Mahasiswa agar menjadi pemimpin masa depan berusaha untuk mempelajari kepemimpinan utuh tersebut sebagai bekal menghadapi tantangan masa depan yang cukup berat. Untuk menjadi kepemimpinan yang utuh, diperlukan pengetahuan maupun keterampilan tertentu, yang meliputi ketajaman visi, memiliki nilai-nilai luhur dan keberanian, dilandasi oleh kompetensi dan didukung oleh kematangan karakter.

Berdasarkan riset kepemimpinan setidaknya ada enam karakter yang terkait dengan kepemimpinan efektif, yaitu sebagai berikut :

1. Dorongan. Pemimpin adalah orang-orang yang memiliki tingkat usaha (dorongan) yang tinggi. Mereka mempunyai kehendak yang kuat untuk pencapaian prestasi. Memiliki ambisi positif, energi yang berlimpah, tak kenal lelah dalam berkegiatan, dan menunjukkan inisiatif dalam banyak hal.

2. Kehendak untuk memimpin. Pemimpin adalah orang yang mempunyai karakter dan kehendak yang kuat untuk memengaruhi dan memimpin orang lain. Mereka menunjukkan kemauan dalam mengemban tanggung jawab, meskipun pekerjaan atau tugas yang diembannya berbahaya atau berisiko.

3. Kejujuran dan integritas. Pemimpin mempunyai keinginan untuk membangun hubungan saling memercayai dan memberi teladan dan menunjukkan konsistensi yang tinggi antara perkataan dan perbuatan.

4. Kepercayaan diri. Para pengikut melihat pemimpinnya tidak ragu-ragu dalam bertindak. Pemimpin perlu menunjukkan kepercayaan dirinya untuk meyakinkan para pengikutnya tentang kebenaran sasaran dan keputusannya.

5. Kecerdasan. Pemimpin adalah orang yang cerdas dan berpengetahuan untuk mengumpulkan, menganalisis, dan menafsirkan informasi. Mereka harus mampu menciptakan visi, memecahkan masalah, dan membuat keputusan yang tepat. 
6. Pengetahuan yang terkait dengan pekerjaan. Pemimpin yang efektif mempunyai tingkat pengetahuan yang tinggi tentang banyak hal, mulai dari perusahaan, industri, dan hal-hal teknis. Pengetahuan yang luas membuat pemimpin dapat membuat keputusan yang cermat.

Menjadi seorang pemimpin bukanlah hal yang mudah, tetapi juga bukan tidak mungkin. Semua usaha yang dilakukan sangat bergantung pada kekuatan kepemimpinan, untuk itu harus dikembangkan. Pemimpin mempunyai ciri-ciri yang berbeda dengan seorang pengikut (follower).

Tabel 8. Followers Vs. Leaders

\begin{tabular}{|l|l|}
\hline \multicolumn{1}{|c|}{ Followers } & \multicolumn{1}{c|}{ Leaders } \\
\hline Beraksi (reaktif) & Berinisiatif \\
\hline Listen; tunggu telepon masuk & Lead; Angkat telepon \\
\hline $\begin{array}{l}\text { Membuang-buang waktu; Reaching to } \\
\text { problems }\end{array}$ & $\begin{array}{l}\text { Gunakan waktu dengan perencanaan dan } \\
\text { antisipasi masalah }\end{array}$ \\
\hline Spend time with people & Invest time with people \\
\hline $\begin{array}{l}\text { Kalender diisi dengan jadwal yang sudah } \\
\text { diperintahkan }\end{array}$ & $\begin{array}{l}\text { Mengisi kalender dengan prioritas- } \\
\text { prioritas ke depan; action }\end{array}$ \\
\hline
\end{tabular}

Sumber: Khasali, dkk (2010)

Demikian pula, pemimpin berbeda dengan manajer. Perbedaan tersebut dapat dilihat pada Tabel 9. Leadership melibatkan tidak hanya kepala (pikiran-pikiran), melainkan juga hati (penciptaan suasana dan menjaga perasaaan). Leadership mencakup kemampuan analisis dan kekuatan interpersonal sekaligus. Menjadi great leader berarti Anda harus siap melakukan perubahan, yaitu perubahan yang terjadi secara bertahap dan membuat usahanya adaptif dalam menghadapi segala situasi yang berubah-ubah. Ada perbedaan mendasar antara management dengan leadership. Management pada dasarnya adalah menyangkut soal keteraturan (penataan) dan pengendalian (control). Sedangkan leadership menyangkut soal pencapain tujuan (achieving goals) dan membuat perubahan. Dalam pandangan yang lain, Maxwell (1982) menyimpulkan leadersip is influence, yaitu kemampuan seseorang untuk menciptakan pengaruh yang luar biasa. Dengan kekuatan itulah, seseorang mengajak kaumnya, bangsanya, atau karyawan-karyawannya keluar dari belenggu tradisi atau kebiasaan-kebiasaan lama (habits).

Tabel 9. Pemimpin VS Manajer

\begin{tabular}{|l|l|}
\hline \multicolumn{1}{|c|}{ Pemimpin } & \multicolumn{1}{c|}{ Manajer } \\
\hline Memperbarui/menciptakan sistem baru & Memelihara / bekerja sistem yang ada. \\
\hline $\begin{array}{l}\text { Bebas, merdeka, kreatif, berani } \\
\text { melakukan kesalahan, tetapi tetap disiplin }\end{array}$ & $\begin{array}{l}\text { Patuh, disiplin, tidak memberi ruang bagi } \\
\text { kesalahan }\end{array}$ \\
\hline Berani menghadapi tantangan & Menghindari risiko \\
\hline $\begin{array}{l}\text { Orientasi ke masa depan di suatu tempat } \\
\text { yang berbeda, imaginatif (be somewhere } \\
\text { one day, learning from the future }\end{array}$ & $\begin{array}{l}\text { Orientasi di sini, hari ini (here \& now), } \\
\text { learning form the past }\end{array}$ \\
\hline Dasarnya adalah kreativitas dan karakter & Menciptakan pengikut dan "bawahan" \\
\hline $\begin{array}{l}\text { Tak terlalu memikirkan posisi, lebih pada } \\
\text { manfaat, nilai dan tanggung jawab }\end{array}$ & $\begin{array}{l}\text { Dasarnya adalah kompetensi dan } \\
\text { profesionalisme. }\end{array}$ \\
\hline Sumber: Khasali, dkk (2010) & \multicolumn{1}{|c}{} \\
\hline
\end{tabular}

Sumber: Khasali, dkk (2010) 
Beberapa cara yang bisa dilakukan untuk memupuk jiwa kepemimpinan, di antaranya sebagai berikut[18]:

1. Bangunlah Pengetahuan, Rajinlah Membaca.

Pepatah lama mengatakan lead today. Kenalilah cara belajar diri sendiri yang efektif. Jangan musuhi sekolah, membenci teori atau terburu-buru mengatakan sesuatu terlalu teoritis. Pemimpin membutuhkan fondasi teori karena mereka yang punya teori bisa melihat lebih jauh dari yang kasat mata. Rajinlah ke kampus, kejar ilmu, belilah dan bacalah buku-buku bermutu, jangan selalu membaca buku-buku yang mudah saja. Namun, janganlah ragu menguji teori-teori itu dengan realitas dan cek apakah itu benar-benar valid.

2. Bukalah Jendela Sel-Sel Diri Sendiri

Kahlil Gibran mengatakan, "Kita semua terpenjara. Yang membedakan kita adalah sebagian tinggal dalam sel-sel berjendela dan yang lainnya tak berjendela." Pemimpin adalah orang yang mendiami sel-sel berjendela dan membuat pintu agar dia bisa mengunjungi sel-sel lainnya. Seorang pemimpin mengenal keberagaman dan berani menghadapi perbedaan.

3. Disiplin Diri

Pemimpin bekerja dengan disiplin yang dimulai dari dirinya sendiri. Ingatlah, perjalanan panjang pengembaraan diri manusia dimulai dari pengembaraan di dalam diri sendiri. Saat manusia bodoh, manusia pasti ingin menguasai orang lain. Namun, saat manusia meraih kebijaksanaan, manusia ingin mengendalikan dirinya sendiri.

4. Bekerjalah dengan Prioritas

Dalam action oriented, akan bertemu dengan konsep prioritas. Pemimpin tahu bagaimana mendahulukan hal-hal yang utama. Kalau seseorang terlalu sibuk dengan segala hal dan menganggap semua urusan itu penting, maka itu pertanda bahwa orang itu belum bekerja dengan prioritas.

5. Kerjakan atau Delegasikan

Kalau bisa dikerjakan, segerelah diselesaikan. Terapkanlah 3D berikut ini: Do it, Delegence it, or Dump it, jangan ditunda-tunda. Masalah sekali dianggap masalah akan tetap menjadi masalah sampai diselesaikan. Kalau sesuatu ditunda, akan menjadi masalah dikemudian hari.

6. Bangunlah Kepercayaan dan Respek

Kepercayaan dan respek didapat karena Anda layak dihormati, berpengetahuan, dan tidak berperilaku sesuka hati. Menjaga komitmen dan peduli terhadap orang lain.

7. Jaga Kestabilan Emosi

Kenali betul kondisi emosi diri sendiri dan kendalikanlah. Gunakan emosi untuk menunjukkan komitmen. Salah satu cara menjaga kestabilan emosi adalah dengan hidup yang seimbang, vertikal maupun horizontal, tidur yang teratur dan menjauhi pemakaian obat-obatan perangsang atau dopping.

8. Latihlah Diri Berkomunikasi dan Mumpuni 
Berinisiatiflah terlibat dalam kegiatan-kegiatan kampus sedari muda. Belajarlah memimpin, menghadapi konflik, mengenal perbedaan pandangan, dan mengatur orang. Tanpa kejelasan komunikasi, tak ada orang yang akan mengikutimu.

9. Belajarlah Menulis

Pemimpin harus bisa menulis dengan logika yang jelas. Belajarlah menulis dan buatlah tulisan-tulisan yang hidup.

10. Gunakan manajemen

Manajemen adalah ilmu yang mengajarkan untuk mencapai tujuan melalui orang lain. Pelajarilah bagaimana merumuskan strategi dan menggerakkan operasional kegiatan dalam satu kesatuan.

Dengan cara tersebut di atas, mahasiswa dapat menumbuhkan jiwa kepemimpinan pada dirinya sendiri. Apabila mahasiswa tidak andal mengatur dirinya sendiri sering melakukan tiga kesalahan di antaranya sebagai berikut:

a. Meremehkan keunikan diri sendiri dengan melakukan yang orang lain inginkan.

b. Menghancurkan efektivitas diri sendiri dengan melakukan hal-hal yang tidak penting. Rumus yang digunakan Maxwell dalam mengelola dirinya supaya efektif yang disebut dengan proses tiga tahap, dapat dilihat pada Tabel 10.

Tabel 10 : Proses Tiga Tahap Mengelola Diri Sendiri supaya Efektif

\begin{tabular}{|c|c|c|}
\hline Tahap & Tingkatan Kebutuhan & Nilai \\
\hline \multirow{5}{*}{$\begin{array}{l}\text { Pertama: Tingkatan } \\
\text { Pentingnya Tugas }\end{array}$} & Mendesak & 5 \\
\hline & Sangat Penting & 4 \\
\hline & Penting & 3 \\
\hline & Berguna & 2 \\
\hline & Kurang Penting & 1 \\
\hline \multirow{5}{*}{$\begin{array}{l}\text { Kedua: } \\
\text { Kapan Tugas itu harus } \\
\text { Selesai }\end{array}$} & Bulan Ini & 5 \\
\hline & Bulan Depan & 4 \\
\hline & Triwulan Ini & 3 \\
\hline & Triwulan Depan & 2 \\
\hline & Akhir Tahun & 1 \\
\hline \multirow{4}{*}{$\begin{array}{l}\text { Ketiga: } \\
\text { Kalikan tingkat } \\
\text { kepentingan dengan } \\
\text { tingkat keterdesakannya }\end{array}$} & \multicolumn{2}{|c|}{$\begin{array}{l}\text { Contoh: } \\
\text { Mendesak (5) X Bulan Depan }(4)=20 \\
\text { Range Nilai: }\end{array}$} \\
\hline & $A=16-25$ & $\begin{array}{l}\text { Tugas mendesak harus } \\
\text { tuntas pada akhir bulan }\end{array}$ \\
\hline & $B=9-15$ & $\begin{array}{l}\text { Tugas penting harus } \\
\text { tuntas pada akhir triwulan }\end{array}$ \\
\hline & $C=1-8$ & $\begin{array}{l}\text { Prioritas rendah harus } \\
\text { tuntas pada akhir tahun }\end{array}$ \\
\hline
\end{tabular}

Sumber: Maxwell (2016)

Sistem ini tidak adanya tugas yang harus dituntaskan pada akhir hari atau minggu, karena untuk merencanakan semua tugas setidaknya satu bulan di muka. Pemimpin sebaiknya melihat lebih jauh ke depan daripada orang lain dalam organisasi. Jika pemimpin selalu menghadapi masalah saat berhadapan dengannya, karyawan dan organisasinya akan menderita. 
c. Mereka mengurangi potensi dengan melakukan hal tanpa bimbingan atau pelatihan. Pelatihan, pembimbingan atau pembinaan dapat sangat memengaruhi produktivitas seseorang dalam menggunakan waktu yang mereka miliki.

\section{KESIMPULAN DAN SARAN}

\section{A. KESIMPULAN}

1. Kurangnya minat mahasiswa untuk mengikuti kegiatan kokurikuler dan ekstrakulikuler yang ada di lingkungan Universitas Pamulang. Data yang diperoleh peneliti melalui wawancara langsung kepada para responden bahwa kebanyakan mahasiswa hanya fokus kepada pendidikan saja yaitu pembelajaran di kelas. Sedangkan sedikit sekali minat mereka untuk melakukan kegiatan di luar kelas. Responden yang terdiri dari Ketua Himpunan Mahasiswa Program Studi dan Ketua Unit Kegiatan Mahasiswa (UKM) hampir didominasi oleh perempuan, dengan perbandingan laki-laki sebanyak $55 \%$ dan perempuan sebanyak $45 \%$. Berdasarkan hasil olah data dari 20 responden yang memiliki "Faktor kepemimpinan yang luar biasa tinggi" yaitu sebanyak 3 orang (15\%), yang memiliki "Faktor kepemimpinan yang sangat tinggi" yaitu sebanyak 4 orang (20\%), dan yang paling banyak pada kualifikasi "Faktor kepemimpinan yang tinggi" yaitu sebanyak 9 orang $(45 \%)$, sedangkan "Faktor kepemimpinan yang di atas rata-rata sebanyak 4 orang $(20 \%)$. Dari data tersebut dapat diketahui bahwa masih dibutuhkan pelatihan kepemimpinan untuk para pengurus HIMA Prodi dan UKM sehingga mereka memiliki jiwa kepemimpinan yang luar biasa tinggi dan juga bisa mencetak mahasiswa lainnya menjadi pemimpin yang lebih baik lagi. Seorang pemimpin dikatakan berhasil apabila bisa menghasilkan pemimpin yang lebih baik lagi di masa yang akan datang.

2. Beberapa cara yang bisa dilakukan untuk memupuk jiwa kepemimpinan, di antaranya sebagai berikutBangunlah Pengetahuan, Rajinlah Membaca; Bukalah Jendela Sel-Sel Diri Sendiri; Disiplin Diri; Bekerjalah dengan Prioritas; Kerjakan atau Delegasikan; Bangunlah Kepercayaan dan Respek; Jaga Kestabilan Emosi; Latihlah Diri Berkomunikasi dan Mumpuni; Belajarlah Menulis; dan Gunakan Manajemen.Dalam menumbuhkan jiwa kepemimpinan kepada para mahasiswa ada tiga poin penting yaitu leadership (kepemimpinan), team working (kerjasama tim) dan communication (komunikasi). Sedangkan untuk menjadi kepemimpinan yang unggul harus memiliki vision, value and couragevisi, value, courage, competence (kompetensi), strong dan nature character yang didukung dengan tiga kecakapan yang harus dimiliki yaitu kecakapan teknis akademis atau knowledge, kecakapan kemanusiaan atau skill, dan kecakapan spiritual

\section{B. SARAN}

Sebaiknya mahasiswa diberikan dukungan moril dan materiil dari pihak Universitas Pamulang sehingga membantu mewujudkan mahasiswa yang beriman dan bertakwa kepada Tuhan Yang Maha Esa dan berakhlak mulia, sehat, berilmu, cakap, kreatif, mandiri, terampil, kompeten, dan berbudaya untuk kepentingan bangsa. Selain itu, dibutuhkannya pelatihan dasar kepemimpinan baik dalam pembelajaran maupun di 
JURNAL ILMIAH ILMU MANAJEMEN

luar pembelajaran, di dalam kelas maupun di luar kelas, sehingga mahasiswa memiliki jiwa kepemimpinan yang bisa memberikan manfaat di kehidupan sehari-hari, baik di kampus, pekerjaan maupun di lingkungan sekitar.

\section{DAFTAR PUSTAKA}

Bachrun S., Buku Induk Manajemen SDM-Human Capital Syariah, Bekasi: LAZIS Dewan Da'wah Islamiyah Indonesia, 2014.

Budiharto S. and F. Himam, "Konstruk Teoritis dan Pengukuran Kepemimpinan Profetik," Jurnal Psikologi, Vo. 33, pp. 133-146, 2006.

Carnegie D., Leadership Mastery Sukses Memimpin Diri Sendiri dan Orang Lain Meraih Posisi \#1, Jakarta: PT Gramedi Pustaka Utama, 2009.

Daswati, "Implementasi Peran Kepemimpinan dengan Gaya Kepemimpinan Menuju Kesuksesan Organisasi," Jurnal Academica Fisip Untad, p. 783, 2012.

Fatwa A., "Pemimpin Jangan Terpenjara Masalah," The Fatwa Center dan Masjid Raya Al-Ittihad, 2013.

Fauzi A., "Membangun Epistemologi Pendidikan Islam Melalui Kepemimpinan Spiritual: Suatu Telaah Diskursif," Empirisma, Vol. 24 No. 2, pp. 155-167, 2015

Handoko H. and Tjiptono F., "Kepemimpinan Transformasional dan Pemberdayaan," Ekonomi dan Bisnis Indonesia, Vol 11 No. 1, 1996.

Kasali R. and dkk, Modul Kewirausahaan untuk Program Strata 1, Jakarta: Hikmah (PT Mizan Publika), 2010.

Maxwell J. C., Pelajaran Penting yang Dibutuhkan Semua Pemimpin, The Leadership Handbook 26, Surabaya: MIC, 2016.

Moeljono D., 13 Konsep Beyond Leadership, Jakarta: PT Elx Media Komputindo, 2017.

Moleoang L. J., Metodologi Penelitian Kualitatif, Bandung: PT Remaja Rosdaharya, 2011.

Raharjo N. E. and Usman, "Strategi Kepemimpinan Pembelajaran Menyongsong Implementasi Kurikulum 2013," Cakrawala Pendidikan, pp. 1-13, 2013.

Sagala S., Pendekatan \& Model Kepemimpinan, Jakarta: Prenadamedia Group, 2018.

Sugiyono, Metode Penelitian Pendidikan: Pendekatan Kuantitatif, Kualitatif dan R\&D, Bandung: Alfabeta, 2012.

Tersiana A., Metode Penelitian, Yogyakarta: Start Up, 2018.

Thoha M., Kepemimpinan dalam Manajemen, Depok: PT Rajagrafindo Persada, 2017.

Ulum M. K. and Suharningsih, "Strategi Pramuka Saka Bhayangkara dalam Upaya Membangun Jiwa Kepemimpinan Remaja di Polsek Kutorejo Kabupaten Mojokerto," Kajian Moral dan Kewarganegaraan. Vol 3 No 4, pp. 1937-1947, 2016. 